\title{
The influence of sex and gender-role orientation in the decision to
}

\section{become an entrepreneur}

\author{
Anna Perez-Quintana \\ Department of Economy and Business, Universitat de Vic, Barcelona, Spain \\ Esther Hormiga \\ Faculty of Economics and Business, University of Barcelona, \\ Barcelona, Spain, and \\ Joan Carles Martori and Rafa Madariaga \\ Department of Economy and Business, Universitat de Vic, Vic, Spain
}

\begin{abstract}
This research explores the relationship between sex, gender-role orientation and the decision to become an entrepreneur. Based on a questionnaire, this article follows the Bem Sex-Role Inventory methodology to perform an analysis by means of multiple regression models. The outcomes show that gender-role orientation is a better predictor of the decision to become an entrepreneur than biological sex. Moreover, the results for whole sample confirm the relationship between masculine and androgynous gender-role orientation and entrepreneurial intention, while there is also evidence of feminine gender-role orientation when we consider only women.
\end{abstract}

Keywords: Gender stereotypes, gender-role orientation, female entrepreneurship, androgyny, entrepreneurial intention. 


\section{Introduction}

Women's empowerment in general and economic development are closely interrelated (Duflo, 2012). Specifically, authors like Maniyalath and Narendran (2016) have provided empirical evidence of a relationship between female entrepreneurship and national income. Traditionally, the literature on female entrepreneurship has analysed this issue from the point of view of biological sex, merely measuring and describing differences between men and women entrepreneurs (Zhang et al, 2009; Piacentini, 2013; Shneor \& Jenssen, 2014; Robb \& Watson, 2010; Kwong et al., 2012). For example, many of them analyse the differences between the types of businesses created and differences in performance indicators (Alas et al., 2015; Dawson \& Henley, 2012; Manolova et al., 2012; Marlow \& McAdam, 2013).

However, entrepreneurship it is not only an economic event but also a cultural issue. Creating a company is a social behaviour, which also makes and constructs gender (Bruni et al., 2004). New perspectives stand against traditional views on male-female differences and the negative effects of making simple comparisons between business created by men and women (Ahl, 2006). Moreover, it points to the need of an alternative theoretical position in gender entrepreneurship (Henry et al., 2015a). In fact, gender stereotypes influence the preferences and choices of individuals in their career (Cejka \& Eagly 1999, Sanchez \& Licciardello, 2012; Martin et al, 2015). Some authors have highlighted the importance of gender stereotypes on entrepreneurial behaviour, specifically on entrepreneurial intentions of men and women (Gupta \& Bhawe, 2007, Gupta et al., 2008, 2009, 2013; Mueller \& Conway Dato-on, 2008, 2013; Ramam, 2014; Fuentes-Fuentes et al. 2015).

Despite of this the studies in the literature of entrepreneurship that analyse the gender-

role orientation compared to biological sex (Watson \& Newby, 2005; Mueller \& Conway Dato- 
on, 2013) are scarce. Thus, as far as we know, this is the first study that updates the gender stereotypes used in the empirical analysis in the specific context of this study. In this regard, this study argues that the key question is not so much what we learn from perspectives based on sex but what we do not consider when we rely solely on a perspective based on sex.

This research proposes the following objectives: (1) to determine the existence of gender stereotypes that influence human behaviour and specially in this research context; (2) to assign gender-role orientation to each individual and, finally (3), to analyse the relationship between entrepreneurial intention, sex and gender-role orientation.

The paper is structured as follows: in the next section we review the theoretical framework of gender stereotypes, the gender schema theory (Bem, 1981) and their relationships with entrepreneurial intention. Then, we present the research context and the methodology that has been used. The fourth section sets out the main results and the fifth presents the conclusions of the study.

\section{Theoretical framework}

\section{Gender stereotypes}

Gender stereotypes refer to socially prevailing beliefs about the characteristics and attributes associated with each sex (Powell \& Graves, 2003). Classifying people using gender stereotypes is a universal procedure, as it allows us to quickly sort them into two groups -men and women- using prominent visual and physical characteristics (Gupta \& Bhawe, 2007). During the socialization process, the adoption of gender stereotypes is encouraged and from the time of birth, a phenomenon of different social empowerment by gender is developed (Wood \& Eagly, 2002). 
The study of the specific attributes that characterise gender stereotypes includes the work of Bem (1974, 1981, 1993), Norman (1963), Rosenkrantz et al. (1968) and Heilman (1983), among many others. There is some consensus in the results. While male stereotyping gives higher priority to instrumental-agent traits (like competition, success orientation, dominant, easily decision taking and risk-taking propensity), female stereotyping appreciates expressive-communal traits (such as tenderness, affection, submission, kindness and gentleness). Further research has shown that the gender stereotypes identified since 1960's are still valid today (Schein, 2001; Twenge, 2001; Wood \& Eagly, 2002; Abele 2003; Mueller \& Conway Dato-on, 2013; Hernández-Bark et al., 2014). Generally, men are expected to be providers, and women care-givers (Watson \& Newby, 2005). Male identity is constructed to be the 'I' protagonist of his life, while female identity is 'for others' (García-Leiva, 2005).

These stereotyped characteristics of both sexes not only describe how men and women are (descriptive stereotypes), but also how they should be (prescriptive stereotypes) (Heilman et al., 2004; Schein, 2001). Descriptive and prescriptive stereotypes are not mutually exclusive. On the contrary, they are largely complementary; prescribed behaviours are clearly identified with the positive attributes for each sex (Gupta et al., 2009). Consequently, prescriptive gender stereotypes make masculine traits desirable for men and undesirable for woman, and vice versa (Gupta \& Bhawe, 2007).

\section{Gender-Role Orientation}

Stemming from gender stereotypes are gender-roles, which constitute the legitimate social functions for both sexes (Eagly \& Steffen, 1984). Gender-Role Orientation (GRO) is defined as the degree of identification of the individual with certain personal attitudes, values, self-concepts, social behaviours and career choices that are consistent with socially constructed gender stereotypes (Beutel \& Marini, 1995; Abele, 2003). Constantinople (1973) argued that 
men are expected to think and act in a masculine way, while women are expected to behave femininely. These assumptions are still present in modern day society (Spence \& Buckner, 2000). Gender-role orientation is a dynamic and multi causal phenomenon in which the subject is an active part of the constant interaction between biology and environment, which in turn are inseparable (García-Leiva, 2005). Moreover, pertaining to a gender category is weightier for women -as the dominated group- than for men -as the dominant group. Women tend to think about themselves in terms of their group characteristics and men tend to do so in terms of their personal characteristics (Moya, 1993).

According to the Gender Schema Theory (Bem, 1981), people's gender typing is the result of gender-schematic processing. Gender-schematic persons tend to process information, including information about themselves, according to the culture's definitions of masculinity and femininity (Bem, 1981). The gender schema theory suggests the interrelatedness of gender related phenomena: gender-personality type, gender attitudes, and gender-related behaviours (Katsurada \& Sugihara, 2002). The Bem Sex-Role Inventory (BSRI) was the tool proposed by Sandra Bem to classify individuals into different gender categories and to measure their genderrole orientation (1974). Her proposal offers an alternative critique of a single bipolar dimension that has been accepted so far by femininity and masculinity. According to Bem, these attributes may not be mutually exclusive in an individual. Therefore, she refuted the belief in a tight correlation between sex -men/women- and gender -masculine/feminine- (Watson \& Newby, 2005). She defined four gender categories, resulting from diverse combinations of the individual's levels of masculine and feminine traits: masculine, feminine, androgynous and undifferentiated.

\section{Gender-role orientation and entrepreneurial intention}


The Theory of Gender Social Role states that society distributes productive and reproductive tasks among members as to guarantee survival (Eagly \& Karau, 2002). The operating rules that try to ensure this purpose result in labour segmentation. The occupational structure of the labour market is shaped by gender through the interaction of three factors. To be part of a group or another -men or women-, the identification of the individual with female and male characteristics -gender-role orientation- and, finally, gender stereotypes, which determine the attitudes of individuals in both decisions, studies and profession (Gupta et al., 2009; Akerlof \& Kranton, 2000). Although there has been a trend for change in recent years, there are still female and male-labelled professions (Martin et al, 2015). That is, expectations and beliefs about the characteristics that men and women bring to their work determine what are considered the most suitable type of jobs for each gender. Some jobs define their necessary traits in terms of gender and become "men's jobs" or "women's jobs" (Ahl, 2006; Gupta et al., 2009; Shinnar et al., 2012; Sanchez \& Licciardello, 2012).

In this context, entrepreneurship has traditionally been considered a male activity (Bird \& Brush, 2002). Our analysis of previous literature highlights that the classical view on entrepreneurship is charged with male stereotypes (De Bruin et al., 2006; Elam, 2008; Watson \& Newby, 2005; Gupta et al., 2009; Wilson \& Tagg, 2010; Javadian, 2014). It is not only the almost unique use of the masculine pronoun, but also the manner by which the entrepreneur is described (Mirchandani, 1999; Ahl, 2006). Traditionally, the entrepreneur has been associated with the figure of the explorer who discovers new lands; a person close to heroism, a patriarch with above-average qualities who stands up within a Darwinian system (Bruni et al., 2004). Moreover, in the archetypal entrepreneurship literature, outstanding qualities have also been linked to leadership and management: the entrepreneur (who discovers new worlds), the leader (who has control) and the manager (who requires sound management skills) (CzarniawskaJoerg \& Wolff, 1991). The successful businessman stereotype has been influenced by the 
culturally dominant masculine attributes, in which size, growth and other performance measures are leading indicators (Watson \& Newby, 2005).

This supremacy is demonstrated in the analysis of the discursive practices of research on female entrepreneurship. Some authors have shown that traits related to the entrepreneur match those that define masculinity, and also that they are opposed to female stereotypical traits (Ahl, 2006; Hancock et al., 2014). While proactivity and risk taking are associated with a masculine symbolic universe, flexibility, adaptability and passivity are connected to a female universe (Ahl, 2006; Wilson \& Tagg, 2010).

Entrepreneurial Intention refers to the decision to become an entrepreneur (Liñán et al., 2011). Based on the Theory of Stereotype Threat (Steele, 1997), when individuals detect a mismatch between their own characteristics and those associated with a stereotyped task, the intentions of carrying out such a task are reduced. In other words, the perceived threat causes a negative evaluation of one's own abilities and a lack of support from the environment is also detected (Gupta \& Bhawe, 2007; Fuentes-Fuentes et al, 2015). This could be the case of entrepreneurial intention. If, as discussed above, the entrepreneur's positive traits are related to males and negative traits to females, female entrepreneurial intention will be influenced by stereotype threat. The threat only operates when the individual is vulnerable and self-perceived as belonging to the group which bears the negative traits. Based on these assumptions the following two hypotheses are tested:

H1: The higher the masculine gender-role orientation of participants, the higher the entrepreneurial intention

H2: The higher the female gender-role orientation of participants, the lower the entrepreneurial intention 
On the other hand, androgynous individuals are those with high scores in masculinity and femininity. The concept of psychological androgyny implies that it is possible for an individual to be both compassionate and assertive, both expressive and instrumental and both feminine and masculine, depending upon the situational appropriateness of these various modalities. It further implies that an individual may even blend these complementary modalities in a single act, such as the ability to fire an employee, if the circumstances require it, but with sensitivity for the human emotion that such an act inevitably produces (Bem, 1981: 4). Watson \& Newby (2005) provide evidence that androgynous people combine a high working capacity with an evident ease for social relations that make them more effective.

Other past studies indicate that androgyny is positively related to entrepreneurial selfefficacy (e.g., Mueller and Conway Dato-On, 2008, 2013) and that androgyny is positively related to effective leadership skills (e.g., Ronit, Ronit \& Boas, 2012; Kark et al., 2012; Ramam, 2014).

When the focus is on entrepreneurs, Goktan \& Gupta (2015) provide evidence that they are more frequently androgynous. The very nature of entrepreneurial activity might contribute to this fact. The activities that an entrepreneur develops sometimes require the kind of abilities related to male roles, like leadership, risk taking or decision making. But they also may require abilities related to female roles, such as flexibility, loyalty or attentiveness. Since entrepreneurial activity is undertaken in an uncertain environment, adaptive capacity and flexibility are needed. Androgynous roles that share some male and female traits may be better suited for these purposes.

Based on these previous results, this research proposes this positive relationship in order to test it: 
H3: The higher the androgynous gender-role orientation of participants, the higher the entrepreneurial intention

\section{Methodology}

In this section the objectives of the research are addressed, i.e.: (1) to determine the existence of gender stereotypes that influence human behaviour and specially in this research context; (2) to measure gender-role orientation to each individual and, finally (3), to analyse the relationship between entrepreneurial intention, sex and gender-role orientation.

\section{The research context}

Catalonia is a Spanish region located in the northeast of the country, between the French border and the Mediterranean Sea. The capital city of Catalonia is Barcelona, and the region is one of the most developed in Spain. It has traditionally been considered the engine of the Spanish economy. In an area that is only $6.5 \%$ of the total area of Spain lives $16 \%$ of the Spanish population, generating around $19.5 \%$ of total Spanish Gross Domestic Product (GDP). As a result, it is more densely populated (232 inhabitants per $\mathrm{km}^{2}$ ) and has a GDP per capita which is more than $15 \%$ higher than and has an activity rate $(62.6 \%)$ three percentage points above the national rate (Spanish Statistical Office, INE, 2015).

The empirical literature has recognized differences between regions and countries in entrepreneur activity with economic development (Wennekers et al., 2005; Carrée et al., 2002), making this is an interesting case to analyse. Among 42 Global Entrepreneurship Monitor (GEM) countries, Spain is ranked 26th for the male/female ratio in early-stage 
entrepreneurship, and 20th for the same ratio in established business owners (Cetindamar et al., 2012). Catalonia is a rich region in a middle-wealth European country where the gender gap in entrepreneur activities can be analysed in the light of cultural and social environment.

Entrepreneurship has played an outstanding role in the development of Catalonia and the on-going economic crisis has made governments and society more aware of this issue. Catalonia is already one of the most entrepreneurial-oriented regions in Spain and southern Europe. In 2014, the entrepreneurial rate of this region was well above $7.5 \%$, which means that $7.5 \%$ of the total population between $18-65$ years old were involved in some entrepreneurial activity in last 42 months (Guallarte et al., 2015). Moreover, in regards to the distribution of self-employed women in Spain, more than $17 \%$ are located in Catalonia (Spanish Statistical Office, INE, 2015).

\section{Sample}

This study uses two different samples of students from the University of Barcelona (which is the highest-ranked Spanish university in the Case Western Reserve University ranking). Following previous studies on the issue (Gupta \& Bhawe, 2007, Gupta et al., 2008, 2009, Mueller \& Conway Dato-on, 2008, 2013; Nwankwo et al., 2012), the respondents attend Business Administration and Management undergraduate programs. There are several advantages and reasons for this sample. On the one hand, the students are familiar with the entrepreneurship issue due to their studies (Begley et al., 2005, Gupta \& Bhawe, 2007; Gupta et al., 2009). Second, they are potential entrepreneurs and perhaps some future entrepreneurs are included in the sample (Thomas \& Mueller, 2000). Thirdly, although most of them have not yet begun their career within an organization or in the creation of their own company, they receive strong stimulus to think about this option. Also cost and ease reasons were considered. One of them was that the questionnaire was distributed in person. 
The 760 participants is a sample of all Business Administration students in Catalonia (Spain) with a margin of error of $3.5 \%$ and a confidence level of $95 \%$. The students were in their first and third years. The reason for this selection it is that in these years they follow subjects related to business creation and entrepreneurship. The interviewers went to the rooms when compulsory subjects were developed. Four first-year rooms and four third-year rooms were visited.

All students in the rooms answered the questionnaires. Two data sets were collected in two different periods, delayed by 2-4 weeks, surveying 380 respondents in Sample 1, and 380 respondents in Sample 2 (two different samples). This procedure reduces variability and provides robustness to the results as the consistency of the responses was considered. Sample 1 was used for identifying gender stereotypes and Sample 2 for determining gender-role orientation of each individual and their relationship with entrepreneurial intention.

\section{Variables measured and analysis}

\section{Gender stereotypes}

For this study, 31 items were selected from the Bem Sex-Role Inventory (Bem, 1981). We follow Ahl (2006) methodology. She previously analysed several foundational texts from entrepreneurship literature and other contemporary articles from management and entrepreneurship research literature focused on the definition of entrepreneurship domain and entrepreneurs. Thus, the items included in Table 1 are used as synonyms or opposites to describe entrepreneurs in management literature (Ahl, 2006; Javadian, 2014). She also provided evidence that the attributes used to describe entrepreneurs are male items in the BSRI. At the same time, the attributes used as being opposite to the entrepreneur are feminine items in BSRI.

In Sample 1 questionnaire respondents were asked about their opinions on how desirable to society is for women and men to have these 31 items, in order to determine gender stereotypes (E.g., "In your opinion, how desirable to society is it for a woman to be individualistic?" "In your opinion, how desirable to society is it for a man to be flexible?"). Since gender is constructed 
and is likely to vary according to time and place, the goal of this section is to determine which items are classified as masculine, feminine, androgynous and undifferentiated, i.e. how gender stereotypes are conceived nowadays (Abele, 2003). For this purpose, a Likert 7-point scale, ranging from 1 (Not at all desirable) to 7 (Extremely desirable), was used for assessing how desirable to society the items for women and men are.

Table 1: Selection of 31 items synonymous or opposites of entrepreneur

\begin{tabular}{ll}
\hline Synonymous & Opposites \\
\hline 1. Self-confident & 1. Kind, attentive \\
2. Prone to taking risk & 2. Gullible \\
3. Prone to position & 3. Flexible \\
4. Individualistic & 4. Loyal \\
5. Determined, steady, temperamental & 5. Sensitive to the needs of the others \\
6. Innovative & 6. No systematic \\
7. Creative & 7. Unpredictable \\
8. Analytical & 8. Obedient \\
9. Assertive & 9. Yielding \\
10. Self-sufficient & 10. Submissive \\
11. Active, energetic, capable of sustained effort & 11. Humble \\
12. Optimistic & 12. Shy, discreet \\
13. Vehement in opinions & \\
14. Leadership capacity & \\
15. Independent & \\
16. Make decisions easily & \\
17. Ambitious & \\
18. Dominant, aggressive & \\
19. Competitive &
\end{tabular}

From 'desirable to society' values obtained in Sample 1, the t-test statistics for all respondents, only for male and only for female respondents were calculated. For an item to be considered masculine, feminine, or androgynous, the condition that the results for the whole group and the subgroups point in the same direction was imposed. Therefore, an item is considered masculine if it is found to have significant differences between 'desirable to society' for a man and a woman, and the average 'desirable to society' for men is higher than the average 'desirable to society' for women. An item is considered feminine if it is found to have significant differences between 'desirable to society' for a man and a woman, and the average 'desirable to society' for women is higher than average 'desirable to society' for men. 
Following the same criteria, an item is considered androgynous if there are no significant differences between 'desirable to society' for a woman and for a man. Finally, the item is considered undifferentiated if there is no unanimity of gender attributes for the three groups (with significance level $p<0.01$ ).

\section{Gender-Role Orientation}

The second step is to assign gender-role orientation to each individual. In order to do this, Sample 2 questionnaire asked respondents to self-define themselves as regards to the same previous 31 items (Washburn-Ormachea et al., 2004). For this purpose a Likert 7-point scale, ranging from 1 (Totally disagree) to 7 (Totally agree), was used for assessing the self-identify of respondents with these items (How do you define yourself?). The averages of each individual on the items grouped as masculine and feminine were computed. According to the methodology used by Bem (1981), the median split is used and compared with these averages to assign each individual an own gender-role orientation. The average value attributed in Sample 1 to male items is 4.99 and the average value attributed to female items is 4.8. If a respondent of Sample 2 rates herself or himself with an average value greater than 4.99 for male items and an average value greater than 4.8 for female items, it means he or she has an Own Androgynous GenderRole Orientation (OAGRO). Likewise, if a respondent rates herself or himself with a value greater than 4.99 in male items and less than 4.8 in female items, he or she has an Own Masculine Gender-Role Orientation (OMGRO). If the opposite happens, he or she has an Own Feminine Gender-Role Orientation (OFGRO). Finally, if she or he is self-rated in male items and female items with lower values than the averages, she or he has an Own Undifferentiated Gender-Role Orientation (OUGRO). Afterwards, woman and men are classified according to their gender-role orientation. 
Using also the scores of Sample 2, other variables were created. We calculate the averages that measure the intensity of the different gender-role orientation for whole sample. These are four continuous variables, termed MGRO, FGRO, AGRO and UGRO. For instance, the intensity of Androgynous GRO is measured taking the average scores for innovative, creative, analytical, unpredictable, active and optimistic (items that are classified as androgynous in Table 5) and dividing by the number of items (here, six). AGRO = (innovative + creative + analytical + unpredictable + active + optimistic $) / 6$. Notice that the result is a quantitative variable, a proxy to measure the incidence of this gender-role orientation in the sample. Table 8 shows descriptive statistics for each gender-role orientation on the second sample.

\section{Control variables}

Two control variables were introduced as they can exert some influence on entrepreneurial intention: on the one hand we controlled if the participants' families actually own a business. Pertaining to a business owner family may have a positive influence on entrepreneurial intention (Zellweger et al, 2015). On the other hand we take into account if the respondents are foreigners as Contín- Pilart \& Larraza- Kintana, (2015) have obtained a positive relationship with the dependent variable. Age was initially considered but the results were not significant and it has therefore been deleted in the results section.

\section{Entrepreneurial Intention}

Entrepreneurial intention is a theoretical concept used to assess the individual attitude regarding entrepreneurship. Following Zhao et al., (2005) and Liñán \& Chen, (2009) six items are presented to individuals of Sample 2 in order to know their level of agreement with the items. A Likert 7-point scale, ranging from 1 (Totally disagree) to 7 (Totally agree), is used. 
Table 2 presents the six items. The "measure" of entrepreneurial intention is obtained averaging the scores of the six items. In order to analyse the reliability of the scale to measure the entrepreneurial intention, Cronbach's alpha coefficient was used. This coefficient measures the internal consistency of the scale, by analysing the correlation of each response with all other responses. The scale shows a high level of consistency with the concept of entrepreneurial intention, well above the recommended standard minimum of $0.7(\alpha(\mathrm{IE})=0.948)$.

\section{Table 2: Entrepreneurial Intention items}

1. I am ready to do anything to be an entrepreneur
2. My professional goal is to become an entrepreneur
3. I will make every effort to start and run my own firm
4. I am determined to create a firm in the future
5. I have very seriously thought of starting a firm
6. I have the firm intention to start a firm some day

In order to assess the explaining capacity of the gender-role orientations we have estimated some regressions. Taking entrepreneur intention as the dependent variable, a regression with sex, business-owning family and foreigner is estimated. Then we add the four gender-role orientation variables to the model to assess whether they improve the results. Finally this last model is estimated separately for women and men to investigate the parameter changes. These results are shown in the next section.

\section{Results}

Table 3 presents the samples' characteristics. As can be seen sex distribution is quite balanced. The average age is around 20 years old. About one third of the respondents belong to families owning a company and around $13 \%$ of participants are foreigners.

Table 3: Samples' Characteristics

\begin{tabular}{lcc}
\hline Sample 1 & Women & Men \\
\hline $\mathrm{N}$ & $189(49.7 \%)$ & $191(50.3 \%)$ \\
Average age & 20.2 years & 21.3 years \\
Range & $18-26$ years & $18-59$ years \\
Families owning business & $38.1 \%$ & $36.6 \%$ \\
Foreigners & $12.2 \%$ & $7.3 \%$
\end{tabular}




\begin{tabular}{lcc}
\hline Sample 2 & Women & Men \\
\hline $\mathrm{N}$ & $180(47.4 \%)$ & $200(52.6 \%)$ \\
Average age & 20.3 years & 20.9 years \\
Range & $18-41$ years & $18-55$ years \\
Families owning business & $36.4 \%$ & $37.5 \%$ \\
Foreigners & $17.6 \%$ & $16 \%$ \\
\hline
\end{tabular}

\section{Gender Stereotypes}

The purpose of this section is to assess whether gender stereotypes play a role in the research context. In other terms, do the instrumental-agent categories for masculine stereotype and expressive-communal categories for feminine stereotype still persist? Does gender socialization achieve its' objectives for men and women? What is the weight of androgynous gender orientation? From Sample 1 questionnaire data, and using statistical t-test $(p<0.01)$ the results point that gender stereotypes persist. There are certain items that are more desirable for men (male items), others which are more desirable for women (female items), others that are equally desirable for women and men (androgynous items) and some items for which there is not an unanimous response, which are qualified as undifferentiated. The results of 31 items are in Appendix I. Table 4 shows an example of the results for each category: 'self-confident' (masculine item), 'humble' (feminine item), 'creative' (androgynous item) and 'yielding' (undifferentiated item).

Table 4: Mean values and SD of 'Desirable to Society' for women and men on various items

\begin{tabular}{|c|c|c|c|c|c|}
\hline Item & Respondents & $\begin{array}{l}\text { Mean (SD) } \\
\text { for women }\end{array}$ & $\begin{array}{l}\text { Mean (SD) } \\
\text { for men }\end{array}$ & $t$-student & $\begin{array}{l}\text { Gender } \\
\text { Category }\end{array}$ \\
\hline \multirow{3}{*}{$\begin{array}{l}\text { Self- } \\
\text { confident }\end{array}$} & All & $5.58(1.267)$ & $6.18(.966)$ & $-9,992 * * *$ & \multirow{3}{*}{ Masculine } \\
\hline & Women & $5.78(1.215)$ & $6.30(.889)$ & $-6,122 * * *$ & \\
\hline & Men & $5.38(1.287)$ & $6.07(1.026)$ & $-8,001 * * *$ & \\
\hline \multirow{4}{*}{ Humble } & All & $5.39(1.287)$ & $4.55(1.538)$ & $9,614 * * *$ & \multirow{3}{*}{ Feminine } \\
\hline & Women & $5.49(1.200)$ & $4.41(1.589)$ & $8,950 * * *$ & \\
\hline & Men & $5.29(1.363)$ & $4.68(1.479)$ & $4,875 * * *$ & \\
\hline & All & $5.48(1.330)$ & $5.35(1.420)$ & 1,455 & \\
\hline
\end{tabular}




\begin{tabular}{llllll}
\hline Creative & Women & $5.52(1.316)$ & $5.20(1.553)$ & $2,541^{* * *}$ & Androgynous \\
& Men & $5.44(1.347)$ & $5.50(1.263)$ & $-0,540$ & \\
\hline \multirow{2}{*}{ Yielding } & All & $3.93(1.585)$ & $3.51(1.639)$ & $3,976^{* * *}$ & \\
& Women & $4.05(1.604)$ & $3.33(1.576)$ & $4,975^{* * *}$ & Undifferentiated \\
& Men & $3.81(1.563)$ & $3.68(1.684)$ & 0,841 & \\
\hline
\end{tabular}

Significance level: $* p<0.1 ; * * p<0.05 ; * * * p<0.01$

Following the methodology previously explained, Table 5 shows all thirty-one items included in the Sample 1 questionnaire. Eleven items result as masculine, eight as feminine, six as androgynous and six as undifferentiated. These results point to the persistence of gender stereotypes showing that masculinity is still associated with instrumental-agent traits (competitive, ease of making decisions, leadership ability, etc.) and femininity with expressivecommunal traits (sensitive to the needs of the others, humble, loyal, etc.). It is also worth observing that some traits closely linked to entrepreneurship (creativity, innovation) are categorized as androgynous. Finally, the implicit dynamism of gender stereotypes means that traditionally masculine (e.g. assertive, self-sufficient) or feminine traits (e.g. yielding, obedient) are considered as undifferentiated. This means that it is not socially expected that individuals (nor men nor women) have to be significantly characterized by those items in the present research context.

Table 5: Items selected and classified by gender stereotypes

\begin{tabular}{llll}
\hline $\begin{array}{l}\text { Masculine } \\
\text { items }\end{array}$ & $\begin{array}{l}\text { Feminine } \\
\text { items }\end{array}$ & $\begin{array}{l}\text { Androgynous } \\
\text { items }\end{array}$ & $\begin{array}{l}\text { Undifferentiated } \\
\text { Items }\end{array}$ \\
\hline Self-confident & Kind, attentive & Innovative & Assertive \\
\hline Prone to taking risk & Gullible & Creative & No systematic \\
\hline Prone to position & Flexible & Analytical & Self-sufficient \\
\hline Individualistic & Loyal & Unpredictable & Obedient \\
\hline $\begin{array}{l}\text { Determined, steady, } \\
\text { temperamental }\end{array}$ & $\begin{array}{l}\text { Sensitive to the } \\
\text { needs of the } \\
\text { others }\end{array}$ & $\begin{array}{l}\text { Active, } \\
\text { energetic, } \\
\text { capable of } \\
\text { sustained effort }\end{array}$ & $\begin{array}{l}\text { Vehement in } \\
\text { opinions }\end{array}$ \\
\hline Leadership capacity & Submissive & Optimistic & Yielding \\
\hline Independent & Humble & & \\
\hline $\begin{array}{l}\text { Make decisions } \\
\text { easily }\end{array}$ & Shy, discreet & & \\
\hline
\end{tabular}




\begin{tabular}{l}
\hline Ambitious \\
\hline Dominant, \\
aggressive \\
\hline Competitive \\
\hline
\end{tabular}

\section{Own Gender-role orientation}

The results from the Sample 2 questionnaire about Own GRO are shown in Table 6. It can be appreciated that women and men are equally self-qualified as androgynous (25\%), and that it is also more common for women to self-qualify as masculine $(22.9 \%)$ than for men to self-qualify as feminine (16.9\%).

Table 6: Sex and Own Gender-Role Orientation

\begin{tabular}{lrrr}
\hline & Women $(\%)$ & Men $(\%)$ & All (\%) \\
\hline Own Masculine GRO (OMGRO) & $35(22.9)$ & $65(35.5)$ & $100(29.8)$ \\
Own Feminine GRO (OFGRO) & $54(35.3)$ & $31(16.9)$ & $85(25.3)$ \\
Own Androgynous GRO (OAGRO) & $39(25.5)$ & $46(25.1)$ & $85(25.3)$ \\
Own Undifferentiated GRO (OUGRO) & $25(16.3)$ & $41(22.4)$ & $66(19.6)$ \\
\hline TOTAL & $153(100.0)$ & $183(100.0)$ & $336(100.0)$ \\
\hline
\end{tabular}

\section{Entrepreneurial Intention}

Table 7 presents means and standard deviations (SD) corresponding to the six items that conform the Entrepreneurial Intention (EI) variable. The table also shows the paired sample ttest, for women, men and jointly. There are significant differences between women and men and it is higher for men than for women.

Table 7: Means and SD by Gender for Items of Entrepreneurial Intention

\begin{tabular}{|c|c|c|c|c|c|}
\hline & $\begin{array}{l}\text { Mean (SD) } \\
\quad \text { All }\end{array}$ & Mean (SD) Women & $\begin{array}{l}\text { Mean }(\mathrm{SD}) \\
\text { Men }\end{array}$ & $\mathrm{F}$ & Sig. \\
\hline Entrepreneurial Intention & $4.80(1.503)$ & $4.53(1.549)$ & $5.04(1.423)$ & 2.149 & $0.001 * * *$ \\
\hline $\begin{array}{l}\text { 1. I am ready to do anything to be } \\
\text { an entrepreneur }\end{array}$ & $4.85(1.482)$ & $4.71(1.501)$ & $4.99(1.458)$ & & \\
\hline $\begin{array}{l}\text { 2. My professional goal is to } \\
\text { become an entrepreneur }\end{array}$ & $4.87(1.637)$ & $4.68(1.704)$ & $5.05(1.556)$ & & \\
\hline $\begin{array}{l}\text { 3. I will make every effort to start } \\
\text { and run my own firm }\end{array}$ & $5.10(1.633)$ & $4.86(1.718)$ & $5.33(1.527)$ & & \\
\hline $\begin{array}{l}\text { 4. I am determined to create a firm } \\
\text { in the future }\end{array}$ & $4.68(1.723)$ & $4.39(1.719)$ & $4.96(1.687)$ & & \\
\hline
\end{tabular}




\begin{tabular}{llll}
\hline $\begin{array}{l}\text { 5. I have very seriously thought of } \\
\text { starting a firm }\end{array}$ & $4.71(1.799)$ & $4.37(1.787)$ & $5.01(1.758)$ \\
\hline $\begin{array}{l}\text { 6. I have the firm intention to start } \\
\text { a firm some day }\end{array}$ & $4.63(1.834)$ & $4.27(1.859)$ & $4.94(1.764)$ \\
\hline$* p \leq 0.1 ; * * p \leq 0.05 * * * * p \leq 0.01$ & & &
\end{tabular}

$* p \leq 0.1 ; * * p \leq 0.05 ; * * * p \leq 0.01$

\section{Gender-role orientation and entrepreneurial intention}

Table 8 shows the correlation coefficients between gender-role orientation and entrepreneurial intention. A positive correlation between entrepreneurial intention, and masculine and androgynous gender orientation are found. There is also no significant correlation between entrepreneurial intention, and feminine and undifferentiated gender orientation.

Table 8: Descriptive statistics and correlations between gender-role orientations and Entrepreneurial Intention

\begin{tabular}{lccccccc}
\hline & Mean & SD & 1. & 2. & 3. & 4. & 5. \\
\hline 1. MGRO & 4.99 & 0.716 & 1 & & & & \\
\hline 2. FGRO & 4.8 & 0.678 & $-0.132^{*}$ & 1 & & & \\
\hline 3. AGRO & 4.99 & 0.743 & $0.560^{* *}$ & 0.040 & 1 & & \\
\hline 4. UGRO & 4.77 & 0.631 & $0.333^{* *}$ & $0.343^{* *}$ & $0.320^{* *}$ & 1 & \\
\hline 5. EI & 4.8 & 1.503 & $0.437^{* *}$ & -0.005 & $0.468^{* *}$ & 0.099 & 1 \\
\hline
\end{tabular}

* Correlation is significant at the 0.05 level (2-tailed) ** Correlation is significant at the 0.01 level (2-tailed)

In order to find out to what extent the gender-role orientation and the sex of participants explains their entrepreneurial intention, a multiple linear regression model has been estimated. The results are presented in Table 9. We began by estimating a simple model -Model 1- with sex, business-owning family and foreigners as explaining variables. As can be appreciated, the model only explains $7.6 \%$ of the variability of the dependent variable. The coefficient of sex is only 0.167 . However, when the four gender-role orientations are added as explaining variables (Model 2), adjusted $\mathrm{R}^{2}$ jumps to $31.4 \%$. These results point show that gender-role orientations are much better predictors of Entrepreneurial Intention than biological sex. Notice also that F 
statistic increases from 11.153 in Model 1 to 19.674 in Model 2, and in this second model the variable sex loses significance since its coefficient decreases to 0.128.

Thus, Model 2 confirms that masculine and androgynous gender-role orientations are significant variables in explaining the entrepreneurial intention of participants. The coefficients of these variables are $0.279(t=4.286, p<0.01)$ and $0.312(t=5.177, p<0.01)$ respectively. These results constitute evidence in favour of $\mathrm{H} 1$ and $\mathrm{H} 3$. However, there is not a significant relationship between feminine gender-role orientation and entrepreneurial intention. Although the coefficient is 0.084 , it is not significant. Notice also that the coefficient of this variable is positive, not negative as $\mathrm{H} 2$ states. This result provides empirical evidence in opposition to the hypothesis.

Applying a stepwise procedure (Stevens, 2012) it is found that androgynous gender-role orientation is the most significant variable in explaining entrepreneurial intention: it accounts for $21.6 \%$. When masculine gender-role orientation is introduced, adjusted $\mathrm{R}^{2}$ reaches $27 \%$. When business-owning family is introduced, adjusted $\mathrm{R}^{2}$ reaches $29 \%$. Finally, when the dichotomous variable sex is considered, $\mathrm{R}^{2}$ increases up to $30.1 \%$. This result provides also empirical evidence that gender-role orientation is a better indicator than sex for the analysis of entrepreneurship issues. Regarding the feminine and undifferentiated gender-role orientations, the results point that there is no relationship with entrepreneurial intention. Table 9 shows that pertaining to a business-owning family exerts influence on entrepreneurial intention; the coefficient is significant and the value is the third in order to explain the variable. Also notice that the other control variable is not significant. These results are in line with the results previously obtained in terms of descriptive attributes of entrepreneurs and the correlation coefficients.

Table 9: Combined effects of gender-role orientation, sex, business-owning family and foreigners on entrepreneurial intention 


\begin{tabular}{|c|c|c|c|c|}
\hline Variables & Model 1 (All) & Model 2 (All) & Model 3 (Women) & Model 4 (Men) \\
\hline Masculine GRO & - & $0.279(4.286) * * *$ & $0.207(2.051)^{* *}$ & $0.363(4.351)^{* * *}$ \\
\hline Feminine GRO & - & $0.084(0.504)$ & $0.146(1.703)^{*}$ & $0.031(0.419)$ \\
\hline Androgynous GRO & - & $0.312(5.177)^{* * *}$ & $0.319(3.270)^{* * *}$ & $0.314(4.031)^{* * *}$ \\
\hline Undifferentiated GRO & - & $0.126(2.132)^{* *}$ & $-0.058(-0.628)$ & $-0.204(-2.582)^{* *}$ \\
\hline $\operatorname{Sex}(0=$ Woman, $1=$ Man $)$ & $0.167(3.354) * * *$ & $0.128(2.522)^{* *}$ & - & - \\
\hline Business-owning family & $0.218(4.354)^{* * *}$ & $0.144(2.857)^{* * *}$ & $0.212(2.640)^{* * *}$ & $0.117(1.743)^{*}$ \\
\hline Foreigners & $0.079(1.588)$ & $0.074(1.478)$ & $0.020(0.256)$ & $0.135(2.046)^{* *}$ \\
\hline$F$ & $11.153 * * *$ & $19.674 * * *$ & $8.360 * * *$ & $14.346 * * *$ \\
\hline Sig. & 0.000 & 0.000 & 0.000 & 0.000 \\
\hline$R^{2}$ & $8.3 \%$ & $33 \%$ & $29.8 \%$ & $35.7 \%$ \\
\hline Adjusted $R^{2}$ & $7.6 \%$ & $31.4 \%$ & $26.3 \%$ & $33.2 \%$ \\
\hline
\end{tabular}

To gain further insights the model is estimated separately for women (Model 3) and men (Model 4). As can be seen also in Table 9, MGRO coefficient is greater for men than for women. In the case of the AGRO coefficient, the opposite result is obtained. Model 3 shows that Androgynous GRO is the most effective on entrepreneurial intention for women, with the coefficient being $0.319(t=3.270, p<0.01)$, the largest in this model. The second explaining variable is Masculine GRO with a coefficient of $0.207(t=2.051)$ but a significance level of only 0.05. The most important result here is that Feminine GRO is significant in explaining entrepreneurial intention for women. Although the coefficient is small (0.146), it is significant at $p<0.1$. This result empirically rejects previous studies that have systematically stated that feminine traits are not relevant for entrepreneurial intention.

Model 4 shows that Masculine GRO is the most influential variable of entrepreneurial intention for men. The coefficient is greater than the one of Androgynous GRO, which is the second most powerful explaining variable. This result demonstrates that both gender-role orientations tend to be significant in explaining entrepreneurial intention. 
Finally, notice that the explanatory power of independent variables, including genderrole orientations are $33 \%$ for men but only $26.3 \%$ for women.

\section{Discussion}

This study shows the persistence of gender stereotypes among a sample of young and future college graduates. The female gender stereotype continues to be linked to the person who is kind, attentive, gullible, flexible, loyal, humble, shy, discreet, submissive and sensitive to the needs of others. In other words, femininity remains characterized by expressive-communal traits (Bem, 1981; Abele, 2003; Ryckman \& Houston, 2003; López-Sáez et al. 2008; Gupta et al., 2009; Gartzia \& Van Engen, 2012; Vafaei et al., 2014). Meanwhile, the male stereotype is related to people who are self-confident, individualistic, independent, ambitious, predisposed to risk taking, and with leadership capacity, who easily take decisions. That is, masculinity is still associated with instrumental-agent traits (Bem, 1981; Heilman, 1983; Gartzia \& Van Engen, 2012; Vafaei et al., 2014).

Along these lines, another important result of this work is the identification of six androgynous items linked directly to entrepreneur stereotypes (Bem, 1981; Ahl, 2006; Hernandez-Bark et al., 2014; Hancock et al., 2014). That is, items that are considered as socially desirable in men and women (innovative, creative, analytical, unpredictable, active-energeticcapable of sustained effort, optimistic). Finally, six items, like assertive, obedient or yielding are not gender-related traits, (Twenge, 2001; Abele, 2003).

According to the results of this study, socialization achieves its objective for a third of the participants: $35 \%$ identify themselves with the prescribed gender-role orientation. Moreover, 25\% of participants are considered androgynous, this being the same proportion for men and women. Following Hofstede (2001), Spain is a low masculine and quite androgynous country ranked 37 th in a masculinity classification for 53 countries. Nevertheless, our results 
shows that gender orientation differs slightly from those obtained for the rest of Spain (Mueller \& Conway Dato-on, 2013; Hernandez-Bark et al., 2014; Vafaei et al., 2014). Mueller \& Conway Dato-on (2013) carried out a comparative study between U.S. and Spain (considering central and southern regions), using BSRI and focusing on gender-role orientation and selfperceived entrepreneurial efficacy. Compared to their results, Catalan women are more likely to be androgynous than in the rest of Spain, while men present a lower propensity to androgyny and greater propensity to masculinity. On the other hand, the results of this study show that there are more women with Own Masculine GRO than men with Own Feminine GRO. According to different authors, this may be due to social change towards less polarization of gender-roles in western countries. In this sense, masculine traits and roles may have become more desirable and accessible for women (Klingenspor, 2002; Hernández-Bark et al., 2014; Gartzia \& van Engen, 2012).

In line with previous studies, the results of this research show that entrepreneurial intention is higher for men than for women (Haus et al., 2013; Gupta et al., 2009; Díaz-García \& Jiménez-Moreno, 2009; Manolova et al., 2012; Shinnar et al., 2012; Pérez-Quintana \& Hormiga, 2012a, 2012b; Karimi et al., 2014).

This research goes further in the field, using a real gender perspective instead of a solely sex based one, something which is uncommon in entrepreneurship research. In this line, different authors assume that the degree of identification of individuals with gender appears as a best predictor of entrepreneurial behaviour compared to biological sex (Gupta et al., 2008, 2009; Mueller \& Conway Dato-on, 2013; Nwankwo et al., 2012; Javadian, 2014; Ramam, 2014). Our results provide empirical evidence for this statement and show that androgynous and masculine gender-role orientation is a better predictor for entrepreneurial intentions than biological sex. 
Regarding the positive influence of masculine gender orientation in entrepreneurial intention, we have to bear in mind that the entrepreneur has traditionally been male (Wood \& Eagly, 2002; Mueller, 2004; Elam, 2008; Ahl, 2006; Nwankwo et al, 2012) and consequently there are fewer female reference models (Justo \& Díaz-García, 2012; Javadian, 2014). The stereotype threat of the entrepreneur is one of the likely reasons for the gender gap in entrepreneurship (Gupta et al., 2009). The threat may be subverted if one thinks that workplaces, jobs or professions are mixed, regardless of whether they have been traditionally held by men or women (Cacouault, 2000; Gartzia \& van Engen, 2012; Nmecha \& Bowen, 2015).

Despite this, women-owned businesses are one of the most rapidly expanding entrepreneurial populations in the world (Brush and Cooper, 2012). Present research has found a very interesting result which is the absence of a negative relationship between feminine gender-role orientation and entrepreneurial intention when we consider only women. This result goes against the idea that being a kind person or being sensitive to the needs of others is incompatible with being an entrepreneur. The new generation of students are exposed to new stereotypes of entrepreneurs; individuals who care for the community, which is clearly exemplified by social entrepreneurs (Mair and Marti, 2006). Indeed, in the last few years, entrepreneurship has been more frequently considered an activity that promotes local, regional and communal development (Campos-Sánchez et al., 2012).

In regards to the positive relationship between androgyny gender-role orientation and entrepreneurship, it is very interesting to analyse the gender stereotypes in the figure of the entrepreneur in the research context of Catalonia, the Spanish region with the most male and female entrepreneurs. Some studies have shown that in the U.S., the masculinity of the entrepreneur is blurring toward androgyny (Hancock et al., 2014; Mueller \& Conway Dato-on, 
2013). Perhaps this evolution is not yet taking place in the rest of Spain or its evolution is slower (Mueller \& Conway Dato-on, 2013; Hernández-Bark et al., 2014). This finding could confirm the emergence of a new entrepreneurial archetype in which androgynous attributes, like innovativeness, optimism, creativity or activity are becoming more usual. In fact, recent work is beginning to emphasize feminine traits for good managers, such as humility or kindness (Gupta et al., 2009; Díaz-García \& Jiménez-Moreno, 2009; Javadian, 2014).

In this work we have taken some synonyms and opposite traits of entrepreneurs to analyse their correspondence with androgynous, masculine, feminine or undifferentiated stereotypes. That is, we have categorized entrepreneur-related traits in terms of gender stereotypes. Then we have analysed the relationship with entrepreneurial intention. Given the implicit dynamism of gender stereotypes (Abele, 2003) we have updated their gender categories. Second, we have classified the respondents according to their own gender-role orientation and their sex. Our results show that more than half of the sample $(65 \%)$ identifies himself or herself with a gender-role orientation which is different to that prescribed by their biological sex. Third, our results show that entrepreneurial intention is better explained by gender-role orientation than by sex. Finally, we have found that Androgynous GRO is the orientation that exerts more influence on entrepreneurial intention, both for women and for men.

\section{Conclusions}

The implicit dynamism in gender-role orientations leads to the possibility of changes in workplace views and especially in entrepreneurship as a career option. In this way, it is possible that the general belief that company owners are men may change. Improving female entrepreneur social visibility, who act as 'role models' may increase female entrepreneur intention. Moreover, emphasis on the androgynous entrepreneur traits in forums at different levels of education, in entrepreneur training activities, will certainly increase female 
entrepreneur intention if they perceive they have positively valued traits for entrepreneurship. Moreover, when we consider only women the fact that there is not a negative relationship between feminine gender-role orientation and entrepreneurial intention leads us to think that enforcing more feminine entrepreneurial stereotypes could help women to identify with this career option.

In line with previous studies that link gender-role orientation and entrepreneurship (Gupta et al., 2009; Mueller \& Conway Dato-on, 2013; Hancock et al., 2014), in this paper we have analysed Business Administration students' views to draw our conclusions. The limitations of this kind of sample have been described in the literature (Hemmasi \& Hoelscher, 2005). The advice is to interview only those undergraduates with high nascent entrepreneurial intention. As we are analysing gender socialization and entrepreneurship, we consider necessary to take into account not only high nascent entrepreneurial intention but also low nascent entrepreneurial intention. This sample can shed light on the process from socialization to decision taking. Furthermore, we have used samples that include homogeneous participants in age and education level (Mueller \& Conway Dato-on, 2013). It is also interesting to consider that the Business Administration degree comprises women and men; this degree is not as gender stereotyped as nursing or engineering. On the other hand, they constitute an interesting group as they learn management skills and entrepreneurial abilities and are equally empowered to undertake entrepreneurial positions (Gielnik et al., 2015). Moreover, the research exclusively focuses on undergraduate students. The professional experience that many of the Master students have can influence the results, should be included in the study. The next step is to apply the gender perspective to advance in the analysis of the features that characterise business managers. Likewise, it would be interesting to continue the study of gender social construction in entrepreneurship focusing on the discourse used by entrepreneurs or in the media. As the 
stereotypes change with the times, it would be really interesting to apply this same study in five years to evaluate any possible changes.

Finally, our conclusions are relevant for educators and trainers of future entrepreneurs. The entrepreneurial archetype evolves from masculinity to androgyny. This may help female entrepreneurial intention. Emphasizing androgynous traits is a way to disable male stereotype domination and threat. This possibility is open, not only for educators who have the ability to improve this perception, but also for the media, advertising companies and women to push and value female entrepreneurship.

\section{References}

Abele, A. E. (2003). The dynamics of masculine-agentic and feminine-communal traits: Findings from a prospective study. Journal of Personality and Social Psychology, 85(4), $768-776$.

Ahl, H. (2006). Why Research on Women Entrepreneurs Needs New Directions. Entrepreneurship: Theory \& Practice, 30(5), 595-621.

Akerlof, G. A., \& Kranton, R. E. (2000). Economics and identity. Quarterly journal of Economics, 715-753.

Alas, R., Vanhala, S., Elenurm, T., Rozell, E. J., \& Scroggins, W. A. (2015). Female Perceptions of Entrepreneurial Success Factors. Journalof BusinessandEconomics, 264.

Begley, T. M., Tan, W., \& Schoch, H. (2005). Politico-Economic Factors Associated with Interest in Starting a Business: A Multi- Country Study. Entrepreneurship: Theory \& Practice, 29(1), 35-55.

Bem, S. (1974). The measurement of psychological androgyny. Journal of Consulting and Clinical Psychology, 42(2), 155-162.

Bem, S. (1981). Gender schema theory: A cognitive account of sex typing. Psychological Review, 88, 354-364.

Bem, S. (1993). The Lenses of Gender: Transforming the Debate on Sexual Inequality. New Haven, CT: Yale University Press.

Beutel, A. M., \& Marini, M. M. (1995). Gender and values. American Sociological Review, 436-448. 
Bird, B., \& Brush, C. G. (2002). Agendered perspective on organizational creation. Entrepreneurship: Theory \& Practice, 26(3), 41-65.

De Bruin, A., Brush, C. G., \& Welter, F. (2007). Advancing a framework for coherent research on women's entrepreneurship. Entrepreneurship theory and practice, 31(3), 323-339.

Bruni, A., Gherardi, S., \& Poggio, B. (2004). Doing Gender, Doing Entrepreneurship: An Ethnographic Account of Intertwined Practices. Gender, Work \& Organization, 11(4), 406-429.

Brush, C. G., \& Cooper, S. Y. (2012). Female entrepreneurship and economic development: An international perspective. Entrepreneurship \& Regional Development, 24(1-2), 1-6.

Cacouault, M. (2000). Variaciones en los empleos femeninos y masculinos. In M. Maruani, C. Rogerat, \& T. Torns (Eds.), Las nuevas fronteras de la desigualdad. Hombres y mujeres en el mercado de trabajo. (pp. 27-34). Barcelona: Icaria.

Campos-Sánchez, A., Hormiga, E., \& Pasola, J. V. (2012). Influencia de los valores personales de la emprendedora sobre la cultura organizativa. Economía industrial, (383), 133-141.

Carrée, M., Van Stel, A., Thurik, R., \& Wennekers, S. (2002). Economic Development and Business Ownership: An Analysis Using Data of 23 OECD Countries in the Period 19761996. Small Business Economics, 19, 271-290.

Cejka, M. A., \& Eagly, A. H. (1999). Gender-Stereotypic Images of Occupations Correspond to the Sex Segregation of Employment. Personality and Social Psychology Bulletin, 25, 413-423.

Cetindamar, D., Gupta, V., Karadeniz, E. E., \& Egrican, N. (2012). What the numbers tell: The impact of human, family and financial capital on women and men's entry into entrepreneurship in Turkey. Entrepreneurship \& Regional Development, 24(1-2), 29-51.

Constantinople, A. (1973). Masculinity-femininity: An exception to a famous dictum? Psychological Bulletin, 80(5), 389.

Contín- Pilart, I., \& Larraza- Kintana, M. (2015). Do Entrepreneurial Role Models Influence the Nascent Entrepreneurial Activity of Immigrants? Journal of Small Business Management.

Czarniawska, B., \& Wolff, R. (1991). Leaders, managers, entrepreneurs on and off the organizational stage. Organization Studies, 12(4), 529-546.

Dawson, C., \& Henley, A. (2015). Gender, risk, and venture creation intentions. Journal of Small Business Management, 53(2), 501-515.

De Bruin, A., Brush, C. G., \& Welter, F. (2006). Towards Building Cumulative Knowledge on Women's Entrepreneurship. Entrepreneurship: Theory \& Practice, 30(5), 585-593. 
Du Rietz, A., \& Henrekson, M. (2000). Testing the female underperformance hypothesis. Small Business Economics, 14(1), 1-10.

Díaz-García, M. C., \& Jiménez-Moreno, J. (2010). Entrepreneurial intention: the role of gender. International Entrepreneurship and Management Journal, 6(3), 261-283.

Duflo, E. (2012). Women empowerment and economic development. Journal of Economic Literature, 50(4), 1051-1079.

Eagly, A. H., \& Karau, S. (2002). Role congruity theory of prejudice toward female leaders. Psychological Bulletin, 109, 573-598.

Eagly, A. H., \& Steffen, V. J. (1984). Gender stereotypes stem from the Distribution of Women and Men Into Social Roles. Journal of Personality and Social Psychology, 46(4), 735754.

Elam, A. B. (2008). Gender and entrepreneurship: A multilevel theory and analysis. Edward Elgar Publishing.

Fishbein, M. \& Ajzen, I. (1975). Belief, attitude, intention and behaviour: An introduction to theory and research. Addison-Wesley.

Fuentes- Fuentes, M.; Bojica, A. M.; Ruiz- Arroyo, M.; Welter, F. (2015). Innovativeness and business relationships in women- owned firms: The role of gender stereotypes. Canadian Journal of Administrative Sciences/Revue Canadienne des Sciences de l'Administration (DOI: 10.1002/cjas.1329).

García-Leiva, P. (2005). Identidad de género: modelos explicativos. Escritos de Psicología, 7 , $71-81$.

Gartzia, L., \& van Engen, M. (2012). Are (male) leaders "feminine" enough? Gender in Management: An International Journal, 27(5), 296-314. doi:10.1108/1754241121125262

Gielnik, M. M., Frese, M., Kahara-Kawuki, A., Katono, I. W., Kyejjusa, S., Ngoma, M. \& Dlugosch, T. J. (2015). Action and action-regulation in entrepreneurship: evaluating a student training for promoting entrepreneurship. Academy of Management Learning \& Education, 14(1), 69-94.

Goktan, A. B., \& Gupta, V. K. (2015). Sex, gender, and individual entrepreneurial orientation: evidence from four countries. International Entrepreneurship and Management Journal, 11(1), 95-112.

Guallarte, C., Capelleras, J. L., Fíguls, M., Genescà, E., Martínez C. \& Obis, T. (2015). GEM : Global Entrepreneurship Monitor, informe ejecutivo Cataluña. Barcelona: Institut d'Estudis Regionals i Metropolitans de Barcelona.

Gupta, V., \& Bhawe, N. (2007). The Influence of Proactive Personality and Stereotype Threat on Women's Entrepreneurial Intentions. Journal of Leadership \& Organizational Studies, 13(4), 73-85. Retrieved from 
Gupta, V., Turban, D. B., \& Bhawe, N. (2008). The effect of gender Stereotype Activation on Entrepreneurial Intentions. Journal of Applied Psychology, 93(5).

Gupta, V., Turban, D. B., \& Pareek, A. (2013). Differences Between Men and Women in Opportunity Evaluation as a Function of Gender Stereotypes and Stereotype Activation. Entrepreneurship: Theory \& Practice, 34(4), 771-788.

Gupta, V., Turban, D. B., Wasti, S. A., \& Sikdar, A. (2009). The Role of Gender Stereotypes in Perceptions of Entrepreneurs and Intentions to Become an Entrepreneur. Entrepreneurship: Theory \& Practice, 33(2), 397-417.

Hancock, C., Pérez-Quintana, A. \& Hormiga, E. (2014). Stereotypical Notions of the Entrepreneur: An Analysis from a Perspective of Gender. Journal of Promotion Management, 20(1), 82-94.

Haus, I., Steinmetz, H., Isidor, R., \& Kabst, R. (2013). Gender effects on entrepreneurial intention: A meta-analytical structural equation model. International Journal of Gender and Entrepreneurship, 5(2), 130-156.

Heilman, M. E. (1983). Sex bias in work settings: The Lack of Fit model. Research in Organizational Behaviour, 5, 269-298.

Heilman, M. E., Wallen, A. S., Fuchs, D., \& Tamkins, M. M. (2004). Penalties for Success: Reactions to Women Who Succeed at Male Gender-Typed Tasks. Journal of Applied Psychology, 89(3), 416-427.

Hemmasi, M., \& Hoelscher, M. (2005). Entrepreneurship research: Using students as proxies for actual entrepreneurs. Journal of Entrepreneurship Education, 8, 49.

Henry, C., Foss, L., \& Ahl, H. (2015a). Gender and entrepreneurship research: A review of methodological approaches. International Small Business Journal, 0266242614549779.

Henry, C., Foss, L., Fayolle, A., Walker, E., \& Duffy, S. (2015b). Entrepreneurial Leadership and Gender: Exploring theory and practice in global contexts. Journal of Small Business Management.

Hernandez Bark, A. S., Escartín, J., \& van Dick, R. (2014). Gender and Leadership in Spain: a Systematic Review of Some Key Aspects. Sex Roles, 70(11-12), 522-537.

Hofstede, G. (2001). Culture's Consequences: Comparing Values, Behaviours, Institutions, and Organizations Across Nations (Vol. 2nd). Thousand Oaks, CA: Sage.

INE, Spanish Statistical Office (2015). Labour force survey.

Javadian, G. (2014). Breaking the Male Norm of Success: How Women Entrepreneurs Benefit from Femininity. Academy of Management, 1-31.

Johnsen, G. J., \& McMahon, R. G. (2005). Owner-manager gender, financial performance and business growth amongst SMEs from Australia's business longitudinal survey. International Small Business Journal, 23(2), 115-142. 
Justo, R., \& Díaz-García, M. C. (2012). Incidencia de los modelos de referencia en la creación de empresas. Efectos mediadores de género. Economía Industrial, 383, 111-123.

Karimi, S., JA Biemans, H., Lans, T., Chizari, M., \& Mulder, M. (2014). Effects of role models and gender on students' entrepreneurial intentions. European Journal of Training and Development, 38(8), 694-727.

Kark, R., Waismel-Manor, R., \& Shamir, B. (2012). Does valuing androgyny and femininity lead to a female advantage? The relationship between gender-role, transformational leadership and identification. The Leadership Quarterly, 23(3), 620-640.

Katsurada, E., \& Sugihara, Y. (2002). Gender-role identity, attitudes toward marriage, and gender-segregated school backgrounds. Sex Roles, 47(5-6), 249-258.

Kepler, E. \& Shane, S. (2007). Are male and female entrepreneurs really that different?. Office of Advocacy, US Small Business Administration.

Klingenspor, B. (2002). Gender-related self-discrepancies and bulimic eating behaviour. Sex Roles, 47(1-2), 51-64.

Kwong, C., Jones-Evans, D., \& Thompson, P. (2012). Differences in perceptions of access to finance between potential male and female entrepreneurs. Evidence from the UK. International Journal of Entrepreneurial Behaviour \& Research, 18(1), 75-97.

Liñán, F., \& Chen, Y. (2009). Development and Cross-Cultural Application of a Specific Instrument to Measure Entrepreneurial Intentions, Entrepreneurship theory and practice, 33(3), 593-617.

Liñán, F., Rodríguez-Cohard, J.C. \& Rueda-Cantuche, J.M. (2011). "Factors affecting entrepreneurial intention levels: a role for education." International entrepreneurship and management Journal, 7(2), 195-218.

López-Sáez, M., Morales, J. F., \& Lisbona, A. (2008). Evolution of gender stereotypes in Spain: traits and roles. The Spanish Journal of Psychology, 11(2), 609-617.

Mair, J., \& Marti, I. (2006). Social entrepreneurship research: A source of explanation, prediction, and delight. Journal of world business, 41(1), 36-44.

Maniyalath, N., \& Narendran, R. (2016). The human development index predicts female entrepreneurship rates. International Journal of Entrepreneurial Behavior \& Research, 22(5), 745-766.

Manolova, T. S., Brush, C. G., Edelman, L. F., \& Shaver, K. G. (2012). One size does not fit all: Entrepreneurial expectancies and growth intentions of US women and men nascent entrepreneurs. Entrepreneurship \& Regional Development, 24(1-2), 7-27.

Marlow, S., \& McAdam, M. (2013). Advancing debate: An epistemological critique of the relationship between gender, entrepreneurship and firm performance. International Journal of Entrepreneurial Behaviour \& Research, 19(1). 
Martin, L., Wright, L., Beavan, Z., \& Matlay, H. (2015). An unusual job for a woman? Female entrepreneurs in scientific, engineering and technology sectors. International Journal of Entrepreneurial Behaviour \& Research, 21(4).

Mirchandani, K. (1999). Feminist Insight on Gendered Work: New Directions in Research on Women and Entrepreneurship. Gender, Work \& Organization, 6(4), 224-235.

Moya Morales, M. C. (1993). Categorías de género: consecuencias cognitivas sobre la identidad. Revista de Psicología Social, 8(2), 171-187.

Mueller, S. L. (2004). Gender gaps in potential for entrepreneurship across countries and cultures. Journal of Developmental Entrepreneurship, 9(3), 199-220.

Mueller, S. L., \& Conway Dato-on, M. (2008). Gender-role orientation as a determinant of entrepreneurial self-efficacy. Journal of Developmental Entrepreneurship, 13(1), 3-20.

Mueller, S. L., \& Conway Dato-on, M. (2013). A cross cultural study of gender-role orientation and entrepreneurial self-efficacy. International Entrepreneurship and Management Journal.

Nmecha, E. E., \& Bowen, G. (2015). Management implication of stereotype or qualification towards female progression. International Journal of Management and Business Economics, 4(4).

Norman, W. T. (1963). Toward an adequate taxonomy of personality attributes: Replicated factor structure in peer nomination personality ratings. The Journal of Abnormal and Social Psychology, 66(6), 574.

Nwankwo, B. E., Kanu, G. C., Marire, M. I., Balogun, S. K., \& Uhiara, A. C. (2012). Genderrole orientation and self-efficacy as correlates of entrepreneurial intention. European Journal of Business and Social Sciences, 1(6), 9-26.

Pérez-Quintana, A., \& Hormiga, E. (2012a). La influencia de los estereotipos de género en la orientación emprendedora individual y la intención de emprender. In Universidad de Sevilla (Ed.), (p. 1511). Sevilla: IV Congreso Universitario Nacional "Investigación y Género."

Pérez-Quintana, A., \& Hormiga, E. (2012b). The influence of gender stereotypes on individual entrepreneurial orientation and intention. In X. C. N. Asociación Científica de Economía y Dirección de la Empresa (ACEDE) (Ed.), XXII Congreso Nacional (p. 86). Universidad de Cádiz.

Piacentini M. (2013). Women entrepreneurs in the OECD: Key evidence and policy challenges, OECD Social, Employment and Migration Working papers. Aviable at: http://www.oecd.org/gender/Enhancing\%20Women\%20Economic\%20Empowerment_ Fin_1_Oct_2014.pdf

Powell, G. N., \& Graves, L. M. (2003). Women and men in management. Thousand Oaks, CA: Sage. 
Ramam, R. S. (2014). An exploration of androgyny in Indian women entrepreneurs. ProcediaSocial and Behavioural Sciences, 133, 304-309.

Robb, A. M., \& Watson, J. (2010). Comparing the performance of female-and male- controlled SMES: Evidence from the United States and Australia. Frontiers of Entrepreneurship Research, 30(8), 1-12.

Ronit, K., Ronit, W., \& Boas, S. (2012). Does valuing androgyny and feminity lead to a female advantage? The relationship between gender-role, transformational leadership, and identification. Leadership Quarterly, 23(3), 620-640.

Rosa, P., Carter, S., \& Hamilton, D. (1996). Gender as a determinant of small business performance: Insights from a British study. Small business economics, 8(6), 463-478.

Rosenkrantz, P., Vogel, S. R., Bee, H., Broverman, I. K., \& Broverman, D. M. (1968). Sexrole stereotypes and self-concept $\mathrm{s}$ in college students. Journal of Consulting and Clinical Psychology, 32, 287-295.

Ryckman, R. M., \& Houston, D. M. (2003). Value priorities in American and British female and male university students. The Journal of Social Psychology, 143(1), 127-138.

Sánchez, Jose C. \& Licciardello, Orazio (2012): Gender Differences and Attitudes in Entrepreneurial Intentions: the Role of Career Choice. Journal of Women's Entrepreneurship and Education, 1-2, 7-27.

Schein, V. E. (2001). A global look at psychological barriers to women's progress in management. Journal of Social issues, 57(4), 675-688.

Shinnar, R. S., Giacomin, O., \& Janssen, F. (2012). Entrepreneurial Perceptions and Intentions: The Role of Gender and Culture. Entrepreneurship: Theory \& Practice, 36(3), 465-493.

Shneor, R. and Jenssen, Jan Inge (2014), "Gender and Entrepreneurial Intentions", in Kelley, L. (ed.), "Entrepreneurial Women: New Management and Leadership Models", Santa Barbara, CA: Praeger Publishing, pp. 15-67.

Spence, J. T., \& Buckner, C. E. (2000). Instrumental and expressive traits, trait stereotypes, and sexist attitudes: What do they signify? Psychology of Women Quarterly, 24(1), 44-53.

Steele, C. (1997). A threat in the air: How stereotypes shape intellectual identity and performance. American Psychologist, 52, 613-629.

Stevens, J. P. (2012). Applied multivariate statistics for the social sciences. Routledge Academic.

Thomas, A. S., \& Mueller, S. L. (2000). A case for comparative entrepreneurship: Assessing the relevance of culture. Journal of International Business Studies, 31(2), 287-301.

Twenge, J. M. (2001). Changes in women's assertiveness in response to status and roles: A cross-temporal meta-analysis. Journal of Personality and Social Psychology, 81, 133-145. 
Vafaei, A., Alvarado, B., Tomás, C., Muro, C., Martinez, B., \& Zunzunegui, M. V. (2014). The validity of the 12-item Bem Sex Role Inventory in older Spanish population: an examination of the androgyny model. Archives of Gerontology and Geriatrics, 59(2), 25763. doi:10.1016/j.archger.2014.05.012

Washburn-Ormachea, J. M., Hillman, S. B. \& Sawilowsky S. S. (2004). Gender and genderrole orientation differences on adolescents' coping with peer stressors. Journal of Youth and Adolescence, 33(1), 31-40.

Watson, J. (2002). Comparing the performance of male-and female-controlled businesses: relating outputs to inputs. Entrepreneurship: Theory and Practice, 26(3), 91-101.

Watson, J., \& Newby, R. (2005). Biological sex, stereotypical sex-roles, and SME owner characteristics. International Journal of Entrepreneurial Behaviour \& Research, 11(2), 129-143.

Welsh D. H. B., Memili E., Kaciak E. and Ahmed S. (2013). "Sudanese women entrepreneurs", Journal of Developmental Entrepreneurship, Vol. 18, No. 2, p. 1.

Wennekers, S., Van Stel, A., Thurik, R., \& Reynolds, P. (2005). Nascent Entrepreneurship and the Level of Economic Development. Small Business Economics, 24, 293-309.

Wilson, F., \& Tagg, S. (2010). Social constructionism and personal constructivism: Getting the business owner's view on the role of sex and gender. International Journal of Gender and Entrepreneurship, 2(1), 68-82.

Wood, W. \& Eagly, A. H. (2002). A cross-cultural analysis of the behaviour of women and men: Implications for the origins of sex differences. Psychological Bulletin, 128, 699-727.

Zellweger, T., Richards, M., Sieger, P., \& Patel, P. C. (2015). How much am I expected to pay for my parents' firm? An institutional logics perspective on family discounts. Entrepreneurship Theory and Practice

Zhang, Z., Zyphur, M. J., Narayanan, J., Arvey, R. D., Chaturvedi, S., Avolio, B. J. \& Larsson, G. (2009). The genetic basis of entrepreneurship: Effects of gender and personality. Organizational Behaviour and Human Decision Processes, 110(2), 93-107.

Zhao, H., Seibert, S. E., \& Hills, G. E. (2005). The Mediating Role of Self-Efficacy in the Development of Entrepreneurial Intentions. Journal of Applied Psychology, 90(6), 12651272

\section{Appendix I}

Mean values and SD of 'desirable to society' for women and men of 31 items 


\begin{tabular}{|c|c|c|c|c|c|}
\hline Items & Respondents & $\begin{array}{l}\text { Mean (SD) } \\
\text { for women }\end{array}$ & $\begin{array}{c}\text { Mean (SD) } \\
\text { for men }\end{array}$ & $t$-student & $\begin{array}{l}\text { Gender } \\
\text { category }\end{array}$ \\
\hline \multirow{3}{*}{ Self-confident } & All & $5.58(1.267)$ & $6.18(.966)$ & $-9.992 * * *$ & \multirow{3}{*}{ Masculine } \\
\hline & Women & $5.78(1.215)$ & $6.30(.889)$ & $-6.122 * * *$ & \\
\hline & Men & $5.38(1.287)$ & $6.07(1.026)$ & $-8.001 * * *$ & \\
\hline \multirow{3}{*}{$\begin{array}{c}\text { Prone to taking } \\
\text { risk }\end{array}$} & All & $4.95(1.546)$ & $5.78(1.130)$ & $-9.300 * * *$ & \multirow{3}{*}{ Masculine } \\
\hline & Women & $5.07(1.524)$ & $5.83(1.164)$ & $-6.072 * * *$ & \\
\hline & Men & $4.83(1.563)$ & $5.73(1.096)$ & $-7.063 * * *$ & \\
\hline \multirow{3}{*}{$\begin{array}{l}\text { Prone to } \\
\text { position }\end{array}$} & All & $5.05(1.346)$ & $5.59(1.124)$ & $-7.284 * * *$ & \multirow{3}{*}{ Masculine } \\
\hline & Women & $5.20(1.350)$ & $5.70(1.128)$ & $-4.538 * * *$ & \\
\hline & Men & $4.89(1.329)$ & $5.49(1.114)$ & $-5.779 * * *$ & \\
\hline \multirow{3}{*}{ Individualistic } & All & $3.42(1.441)$ & $4.19(1.651)$ & $-8.417 * * *$ & \multirow{3}{*}{ Masculine } \\
\hline & Women & $3.51(1.475)$ & $4.28(1.643)$ & $-5.955 * * *$ & \\
\hline & Men & $3.32(1.405)$ & $4.11(1.658)$ & $-5.936 * * *$ & \\
\hline \multirow{3}{*}{$\begin{array}{l}\text { Determined, } \\
\text { Steady, } \\
\text { temperamental }\end{array}$} & All & $5.23(1.409)$ & $5.74(1.147)$ & $-6.137 * * *$ & \multirow{3}{*}{ Masculine } \\
\hline & Women & $5.40(1.435)$ & $5.77(1.194)$ & $-3.149 * * *$ & \\
\hline & Men & $5.06(1.367)$ & $5.70(1.100)$ & $-5.557 * * *$ & \\
\hline \multirow{3}{*}{$\begin{array}{l}\text { Leadership } \\
\text { capacity }\end{array}$} & All & $5.10(1.471)$ & $5.89(1.241)$ & $-8.633 * * *$ & \multirow{3}{*}{ Masculine } \\
\hline & Women & $5.16(1.533)$ & $5.93(1.232)$ & $-5.968 * * *$ & \\
\hline & Men & $5.04(1.408)$ & $5.85(1.253)$ & $-6.223 * * *$ & \\
\hline \multirow{3}{*}{ Independent } & All & $4.95(1.415)$ & $5.33(1.370)$ & $-4.536 * * *$ & \multirow{3}{*}{ Masculine } \\
\hline & Women & $4.99(1.447)$ & $5.42(1.389)$ & $-3.499 * * *$ & \\
\hline & Men & $4.91(1.386)$ & $5.24(1.349)$ & $-2.897 * * *$ & \\
\hline \multirow{3}{*}{$\begin{array}{c}\text { Make decisions } \\
\text { easily }\end{array}$} & All & $4.89(1.456)$ & $5.42(1.224)$ & $-6.206 * * *$ & \multirow{3}{*}{ Masculine } \\
\hline & Women & $5.02(1.474)$ & $5.52(1.247)$ & $-4.286 * * *$ & \\
\hline & Men & $4.76(1.430)$ & $5.32(1.196)$ & $-4.479 * * *$ & \\
\hline \multirow{3}{*}{ Ambitious } & All & $5.00(1.362)$ & $5.76(1.123)$ & $-10.042 * * *$ & \multirow{3}{*}{ Masculine } \\
\hline & Women & $4.89(1.441)$ & $5.79(1.100)$ & $-8.146 * * *$ & \\
\hline & Men & $5.11(1.275)$ & $5.74(1.147)$ & $-6.059 * * *$ & \\
\hline \multirow{3}{*}{ Items } & & Mean (SD) & Mean (SD) & & \multirow{3}{*}{$\begin{array}{c}\text { Gender } \\
\text { category }\end{array}$} \\
\hline & Respondents & for women & for men & $t$-student & \\
\hline & All & $3.28(1.528)$ & 4.15 (1.776) & $-8.458 * * *$ & \\
\hline
\end{tabular}




\begin{tabular}{|c|c|c|c|c|c|}
\hline \multirow{2}{*}{$\begin{array}{l}\text { Dominant, } \\
\text { aggressive }\end{array}$} & Women & $3.32(1.611)$ & $4.12(1.877)$ & $-5.293 * * *$ & \multirow[t]{2}{*}{ Masculine } \\
\hline & Men & $3.24(1.445)$ & $4.19(1.674)$ & $-6.702 * * *$ & \\
\hline \multirow{3}{*}{ Competitive } & All & $5.31(1.391)$ & $6.08(1.059)$ & $-10.149 * * *$ & \multirow{3}{*}{ Masculine } \\
\hline & Women & $5.30(1.447)$ & $6.11(1.038)$ & $-7.335 * * *$ & \\
\hline & Men & $5.32(1.337)$ & $6.04(1.080)$ & $-7.003 * * *$ & \\
\hline \multirow{3}{*}{ Kind, attentive } & All & $5.94(1.092)$ & $5.06(1.370)$ & $11.505 * * *$ & \multirow{3}{*}{ Feminine } \\
\hline & Women & $6.04(1.018)$ & $4.98(1.420)$ & $9.793 * * *$ & \\
\hline & Men & $5.84(1.153)$ & $5.14(1.318)$ & $6.604 * * *$ & \\
\hline \multirow{3}{*}{ Gullible } & All & $3.21(1.743)$ & $2.48(1.386)$ & $7.203 * * *$ & \multirow{3}{*}{ Feminine } \\
\hline & Women & $3.28(1.798)$ & $2.32(1.287)$ & $7.075 * * *$ & \\
\hline & Men & $3.13(1.688)$ & $2.63(1.465)$ & $3.340 * * *$ & \\
\hline \multirow{3}{*}{ Flexible } & All & $5.16(1.462)$ & $4.36(1.430)$ & $8.017 * * *$ & \multirow{3}{*}{ Feminine } \\
\hline & Women & $5.36(1.472)$ & $4.36(1.483)$ & $6.897 * * *$ & \\
\hline & Men & $4.96(1.427)$ & $4.37(1.380)$ & $4.398 * * *$ & \\
\hline \multirow{3}{*}{ Loyal } & All & $5.66(1.283)$ & $5.13(1.343)$ & $6.917 * * *$ & \multirow{3}{*}{ Feminine } \\
\hline & Women & 5.74 (1.197) & $5.05(1.319)$ & $7.115 * * *$ & \\
\hline & Men & $5.57(1.362)$ & $5.20(1.365)$ & $3.165 * * *$ & \\
\hline \multirow{3}{*}{$\begin{array}{l}\text { Sensitive to the } \\
\text { needs of the } \\
\text { others }\end{array}$} & All & $5.37(1.300)$ & $4.26(1.519)$ & $11.159 * * *$ & \multirow{3}{*}{ Feminine } \\
\hline & Women & $5.42(1.298)$ & $4.08(1.524)$ & $9.255^{* * *} *$ & \\
\hline & Men & $5.32(1.303)$ & $4.44(1.496)$ & $6.564 * * *$ & \\
\hline \multirow{3}{*}{ Submissive } & All & $3.32(1.837)$ & $2.64(1.458)$ & $6.565 * * *$ & \multirow{3}{*}{ Feminine } \\
\hline & Women & $3.32(1.913)$ & $2.53(1.429)$ & $5.229 * * *$ & \\
\hline & Men & $3.33(1.765)$ & $2.74(1.481)$ & $4.048 * * *$ & \\
\hline \multirow{3}{*}{ Humble } & All & $5.39(1.287)$ & $4.55(1.538)$ & $9.614 * * *$ & \multirow{3}{*}{ Feminine } \\
\hline & Women & $5.49(1.200)$ & $4.41(1.589)$ & $8.950 * * *$ & \\
\hline & Men & $5.29(1.363)$ & $4.68(1.479)$ & $4.875 * * *$ & \\
\hline \multirow{3}{*}{ Shy, discreet } & All & $3.42(1.595)$ & $2.81(1.399)$ & $6.605 * * *$ & \multirow{3}{*}{ Feminine } \\
\hline & Women & $3.39(1.638)$ & $2.72(1.375)$ & $4.934 * * *$ & \\
\hline & Men & $3.45(1.556)$ & $2.90(1.419)$ & $4.386 * * *$ & \\
\hline \multirow{3}{*}{ Items } & & Mean (SD) & Mean (SD) & & \multirow{3}{*}{$\begin{array}{l}\text { Gender } \\
\text { category }\end{array}$} \\
\hline & Respondents & for women & for men & $t$-student & \\
\hline & All & $5.54(1.251)$ & $5.68(1.145)$ & $-2.053 * *$ & \\
\hline
\end{tabular}




\begin{tabular}{|c|c|c|c|c|c|}
\hline \multirow[t]{2}{*}{ Innovative } & Women & $5.62(1.253)$ & $5.68(1.242)$ & -0.642 & \multirow[t]{2}{*}{ Androgynous } \\
\hline & Men & $5.47(1.247)$ & $5.68(1.042)$ & $-2.257 * *$ & \\
\hline \multirow{3}{*}{ Creative } & All & $5.48(1.330)$ & $5.35(1.420)$ & 1.455 & \multirow{3}{*}{ Androgynous } \\
\hline & Women & $5.52(1.316)$ & $5.20(1.553)$ & $2.541 * *$ & \\
\hline & Men & $5.44(1.347)$ & $5.50(1.263)$ & -0.540 & \\
\hline \multirow{3}{*}{ Analytical } & All & $5.06(1.223)$ & $5.17(1.204)$ & -1.541 & \multirow{3}{*}{ Androgynous } \\
\hline & Women & $5.08(1.208)$ & $5.11(1.240)$ & -0.323 & \\
\hline & Men & $5.05(1.241)$ & $5.23(1.167)$ & $-1.879 *$ & \\
\hline \multirow{3}{*}{ Unpredictable } & All & $4.18(1.486)$ & $4.38(1.376)$ & $-2.260 * *$ & \multirow{3}{*}{ Androgynous } \\
\hline & Women & $4.18(1.478)$ & $4.48(1.379)$ & $-2.409 * *$ & \\
\hline & Men & $4.18(1.498)$ & $4.28(1.370)$ & -0.810 & \\
\hline \multirow{3}{*}{$\begin{array}{c}\text { Active, } \\
\text { energetic, } \\
\text { capable of } \\
\text { sustained effort }\end{array}$} & All & $5.59(1.286)$ & $5.80(1.205)$ & $-2.706^{* *}$ & \multirow{3}{*}{ Androgynous } \\
\hline & Women & $5.68(1.287)$ & $5.84(1.215)$ & -1.394 & \\
\hline & Men & $5.50(1.281)$ & $5.77(1.196)$ & $-2.437 * *$ & \\
\hline \multirow{3}{*}{ Optimistic } & All & $5.44(1.253)$ & $5.52(1.294)$ & -1.115 & \multirow{3}{*}{ Androgynous } \\
\hline & Women & $5.56(1.242)$ & $5.52(1.366)$ & 0.501 & \\
\hline & Men & $5.32(1.256)$ & $5.52(1.222)$ & $-2.030 * *$ & \\
\hline \multirow{3}{*}{ Assertive } & All & $4.61(1.451)$ & $5.10(1.376)$ & $-5.527 * * *$ & \multirow{3}{*}{ Undifferentiated } \\
\hline & Women & $4.66(1.521)$ & $5.28(1.349)$ & $-5.227 * * *$ & \\
\hline & Men & $4.56(1.378)$ & $4.92(1.382)$ & $-2.709 * *$ & \\
\hline \multirow{3}{*}{ No systematic } & All & $3.94(1.439)$ & $4.20(1.359)$ & $-3.245 * * *$ & \multirow{3}{*}{ Undifferentiated } \\
\hline & Women & $3.85(1.452)$ & $4.18(1.458)$ & $-2.752 * * *$ & \\
\hline & Men & $4.04(1.423)$ & $4.23(1.255)$ & $-1.785^{*}$ & \\
\hline \multirow{3}{*}{ Self-sufficient } & All & $5.40(1.442)$ & $5.74(1.225)$ & $-4.228 * * *$ & \multirow{3}{*}{ Undifferentiated } \\
\hline & Women & $5.45(1.452)$ & $5.74(1.285)$ & $-2.370 * *$ & \\
\hline & Men & $5.35(1.434)$ & $5.74(1.166)$ & $-3.705 * * *$ & \\
\hline \multirow{4}{*}{ Obedient } & All & $4.45(1.703)$ & $4.04(1.564)$ & $4.028 * * *$ & \multirow{3}{*}{ Undifferentiated } \\
\hline & Women & $4.53(1.788)$ & $4.02(1.553)$ & $3.688 * * *$ & \\
\hline & Men & $4.37(1.617)$ & $4.06(1.579)$ & $2.084 * *$ & \\
\hline & & Mean (SD) & Mean (SD) & & Gender \\
\hline \multirow[t]{2}{*}{ Items } & Respondents & for women & for men & $t$-student & category \\
\hline & All & $5.27(1.381)$ & $5.53(1.247)$ & $-3.482 * * *$ & \\
\hline
\end{tabular}




\begin{tabular}{clllll}
\hline \multirow{2}{*}{$\begin{array}{c}\text { Vehement in } \\
\text { opinions }\end{array}$} & Women & $5.38(1.322)$ & $5.64(1.226)$ & $-2.661^{* * *}$ & Undifferentiated \\
\cline { 2 - 4 } & Men & $5.15(1.430)$ & $5.41(1.260)$ & $-2.303^{* *}$ & \\
\hline \multirow{3}{*}{ Yielding } & All & $3.93(1.585)$ & $3.51(1.639)$ & $3.976^{* * *}$ & \\
\cline { 2 - 4 } & Women & $4.05(1.604)$ & $3.33(1.576)$ & $4.975^{* * *}$ & \\
\cline { 2 - 4 } & Men & $3.81(1.563)$ & $3.68(1.684)$ & 0.841 & \\
\hline
\end{tabular}

Significance level: $* p \leq 0.1 ; * * p \leq 0.05 ; * * * p \leq 0.01$ 